\title{
Foliar analysis in experimentally grown Laca- tan bananas in relation to leaf production and bunch weight
}

\author{
W. J. BRZESOWSKY and J. VAN BIESEN \\ Former Soil Scientist and Research Chemist resp. with the Cameroons Development \\ Corporation, Cameroon Republic
}

\begin{abstract}
Summary
The technique of foliar diagnosis and its results in relation to leaf and fruit production of Lacatan bananas (plant crop) are discussed, particularly in view of potash demands during the dry season in case the banana crop is grown on young volcanic non-irrigated soils, with an inherently low potash availability.
\end{abstract}

\section{Introduction}

Foliar diagnosis in bananas was carried out for the first time by HewITT (1955) in Jamaica and tentative leaf nutrient values were established by him based on the use of the third leaf of "shot" plants as the standard leaf for sampling.

The sampling technique in the Monocotyledons proves to be much easier as compared with Dicotyledon crops, due to the serial progression of the leaves at fairly regular intervals (MURRAY, 1960). In the latter crops the physiological age of the leaf at the time of sampling is often difficult to ascertain.

Although a constant rate of growth (e.g. leaf production) may safely be assumed under fairly uniform climatic conditions during the cropping season, the intervals at which leaves are progessively produced may be liable to distinct fluctuations if pronounced differences in the climate exist between different seasons of the year. The latter may particularly cause differences in the physiological age of older leaves used as the standard leaf for monthly sampling.

Since potassium, highly demanded by the banana plant, tends to accumulate in the youngest fully opened leaf, monthly leaf samples were taken in a Lacatan banana fertilizer trial from the first fully opened green leaf. The samples were chemically analysed for the five major elements, e.g. nitrogen, phosphorus, potassium, calcium and magnesium. The results are expressed as a percentage on dry matter. A leaf count was made every fortnight.

Fruit was harvested at weekly intervals at full grade standards and weighed. The experiment was sprayed with a water-based copper fungicide against Sigatoka Leaf Spot disease every fortnight.

Received for publication 14th December, 1961. 


\section{Methods used}

\subsection{Fertilizer trial}

Hasselo (1961) earlier reported on the design of the fertilizer trial, situated on the eastern slopes of the Cameroon Mountain.

The Lacatan banana fertilizer trial was of a randomized block design with six treatments in four replications. Each plot of 72 plants was surrounded by a single guard row, the planting density being 512 plants per acre. The six NPK-treatments were : $1 \mathrm{~N}-1 \mathrm{P}-1 \mathrm{~K}, 1 \mathrm{~N}-1 \mathrm{P}-2 \mathrm{~K}, 1 \mathrm{~N}-1 \mathrm{P}-3 \mathrm{~K}, 2 \mathrm{~N}-1 \mathrm{P}-1 \mathrm{~K}, 2 \mathrm{~N}-1 \mathrm{P}-2 \mathrm{~K}$ and $2 \mathrm{~N}-1 \mathrm{P}-3 \mathrm{~K}$, consisting of the following amounts of fertilizer applied in two equal amounts before and after the rains :

$1 \mathrm{~N}=300 \mathrm{lb} /$ acre per annum sulphate of ammonia

$2 \mathrm{~N}=600 \quad " \quad, \quad " \quad$ sulphate of ammonia

$1 \mathrm{P}=400 \quad " \quad, \quad " \quad, \quad$ super phosphate

$1 \mathrm{~K}=300 \quad, \quad " \quad, \quad$ muriate of potash $(50 \%)$

$2 \mathrm{~K}=600 \quad, \quad, \quad, \quad$ muriate of potash $(50 \%)$

$3 \mathrm{~K}=900 \quad, \quad " \quad$ " muriate of potash $(50 \%)$

The ratio in quantity of NPK-fertilizer between treatments $2 \mathrm{~N}-1 \mathrm{P}-3 \mathrm{~K}$ and $1 \mathrm{~N}-$ $1 \mathrm{P}-3 \mathrm{~K}$ amounts to approximately 1,5 .

\subsection{Grow th measurements}

Considerable growth is possible from the store of nutrients in the corm of the banana plant. MurRaY (1960) estimated that on average the plant may produce its half dozen leaves with reserves of all nutrients except nitrogen in the corm.

In practice, the appearance of the plant crop in its young stage highly depends upon the size of the original sucker. A ratoon crop may yield a much heavier crop in comparison with the plant crop. The trial was planted up with uniformly sized Lacatan seed at the beginning of May 1959. Leaf count was started and thought to be the true reflection of the nutritional level in the soil, approximately 4-5 months afterwards, i.e. September 1959. On the other hand leaf count ceased at the time slightly prior to shooting. In each of 24 plots available, 25 plants were selected on uniformity (e.g. height, number of leaves, leaf length and width of the first fully developed leaf) at random. At the first and successive recording dates, the first fully developed leaf was marked with clearly visible paint. The leaves produced by each of the 25 selected plants were recorded at fortnightly intervals and the average leaf production per plant per plot obtained by calculation.

\subsection{The choice of the standard leaf}

It is the main aim of the leaf sampling investigations in fruit bearing crops to indicate the plant's nutritional status, preferably prior to the initiation of flowering.

By using leaves of an early growth stage, any deficiency of a particular nutrient or incorrect ratio between two or more nutrients, may be detected and corrected successfully prior to fruit setting.

The following reasons led us to the choice of the standard leaf :

a. Pronounced climatic differences exist between different seasons of the year, particularly on the eastern slopes of the Cameroon Mountain where the experimental site is situated. 
Rainfall is rather abundant during July-November, whilst a severe dry season prevails from November/December-February/March :

TABLE 1. Rainfall in inches

\begin{tabular}{ccccccccccccc}
\hline J. & F. & M. & A. & M. & J. & J. & A. & S. & O. & N. & D. & Total \\
1,8 & 1,5 & 4,3 & 6,3 & 7,7 & 11,1 & 16,1 & 17,3 & 12,7 & 11,2 & 3,7 & 0,8 & 94,5 \\
\hline
\end{tabular}

The physiological age of each leaf on the plant at a particular date will be different in the wet and dry season. The use of a young leaf will reduce these differences.

b. Bananas are highly demanding for potassium (RISBETH, 1960) and in the Cameroons large responses from potash fertilizing on young volcanic soils were obtained by Hasselo (1961 a, b). Potassium concentrations decrease with age of leaf, being highest in the first fully opened leaf (HewitT, 1955; Boland, 1957/58). On the other hand in bananas only calcium concentrations increase distinctly with age of leaf (MURRAY, 1960). Therefore, in order to minimize physiological differences between the monthly sampled leaves and in view of the high demands of bananas for potash, the latest fully developed green leaf was chosen as the standard sampled leaf.

\subsection{Leaf s a mpling}

In order to reduce the physical damage of the plants caused by the leaf sampling, a sampling method was worked out similar to that outlined by Prevot and OLLAGNIER (1953) and BROESHART (1955) for oilpalms.

From the first fully developed green leaf, which remained on the plant, two strips of 3-4 inches wide on either side of the midrib in the centre of the leaf were removed. Initially, when the standard leaf was within easy reach, the strips were simply tom off by hand. At a later stage when the plant had grown taller, small knives attached to long sticks were used similar to those described by BoLAND (1957/58).

A total of 1800 plants, including those present in an additional control plot were sampled at four-weekly intervals. Approximately 72 plants were sampled per plot and a total of 25 bulk samples were obtained at every sample date. Only non-shot plants were sampled.

After shooting of the plants and the harvesting of the fruit, the sampling was recontinued on the first follower. Since the trial was sprayed with a water-based copper fungicide every fortnight, sampling was carried out prior to spraying in order to avoid contamination.

Sampling was completed between 7 a.m. and 9 a.m.. Bulk samples were packed in polythene bags and sent to the laboratory. Drying of the bulk samples was carried out immediately afterwards.

\subsection{Preparation of the samples}

The samples were dry cleaned with a rag to remove the dust and dried at $70{ }^{\circ} \mathrm{C}$ for 24 hours. They were ground in a grinding mill with a $2,45 \mathrm{~mm}$ screen and finally dried for one hour at $105^{\circ} \mathrm{C}$.

All samples were analysed for nitrogen within five days after sampling. For the determination of phosphorus, calcium and magnesium, the samples were pre-charred at $150{ }^{\circ} \mathrm{C}$, kept for 2 hours at $300{ }^{\circ} \mathrm{C}$ and finally ashed at $500{ }^{\circ} \mathrm{C}$ for a further 
2 hours. A pure white ash was then obtained. When ground to a fine powder as suggested by BOLAND (1957/58), ashing time increased considerably and it was found difficult to obtain a white ash. For the determination of potassium the samples were not ashed.

Since it has been previously found at W.A.I.F.O.R. (Anon. 1959) that the determined leaf-K content fluctuates with the ashing temperatures, it was decided to extract the plant material in a solution of $0,5 \mathrm{~N} \mathrm{HCL}$ for 48 hours at room temperature.

\subsection{Analytical methods}

The following analytical methods were used :
a. Nitrogen
Macro Kjeldahl
b. Phosphorus
Stannous chloride
c. Potassium
Flame photometry
d. Calcium
Oxalate
e. Magnesium
Pyrophosphate

Data are expressed as a percentage of dry matter.

\section{Results and discussions}

It was reported earlier by Hasselo (1961 a) that during the dry season no "premature yellowing", resulting from potash deficiency, was apparent in the fertiliser trial, except in the buffer rows and some of the plots receiving the double dressing of nitrogen at a low potash level (treatment $2 \mathrm{~N}-1 \mathrm{P}-1 \mathrm{~K}$ ). The leaf symptoms in this particular trial, however, were not as marked as in the plantation bananas. This difference in degree of deficiency symptoms was explained to be due to the presence of eel worms in the latter bananas, causing damage to the root system and resulting in a reduction of the uptake of potash from a soil with an inherently low potash availability.

The total number of leaves produced per plant is given in TABLE 2 for the period $3 / 10 / 59-2 / 4 / 60$, i.e. 26 weeks. The period largely covers the greater part of the dry season.

TABLE 2. Number of leaves produced in 26 weeks per plant per treatment; mean of 4 replications

Number of leaves produced
per plant in 26 weeks

\begin{tabular}{|c|c|c|}
\hline $1 \mathrm{~N}-1 \mathrm{P}-1 \mathrm{~K}$ & $17,2(100)$ & \\
\hline $1 \mathrm{~N}-1 \mathrm{P}-2 \mathrm{~K}$ & $17,6(102)$ & \\
\hline $1 \mathrm{~N}-1 \mathrm{P}-3 \mathrm{~K}$ & $17,5(102)$ & \\
\hline $2 \mathrm{~N}-1 \mathrm{P}-1 \mathrm{~K}$ & $17,2(100)$ & S.D. at $5 \%= \pm 1,0$ \\
\hline $2 \mathrm{~N}-1 \mathrm{P}-2 \mathrm{~K}$ & $18,0(105)$ & S.D. at $1 \%= \pm 1,4$ \\
\hline $2 N-1 P-3 K$ & $18,6(108)$ & \\
\hline
\end{tabular}

The main effect of potash was nearly significant and positive $(F=3,38$ against 3,68 at $5 \%$ ).

Treatment $2 \mathrm{~N}-1 \mathrm{P}-3 \mathrm{~K}$ produced highly significant more leaves than treatment $1 \mathrm{~N}-$ $1 \mathrm{P}-1 \mathrm{~K}$ and treatment $2 \mathrm{~N}-1 \mathrm{P}-1 \mathrm{~K}$. The difference between treatments $1 \mathrm{~N}-1 \mathrm{P}-3 \mathrm{~K}$ 
and $2 \mathrm{~N}-1 \mathrm{P}-3 \mathrm{~K}$ proved also to be significant. The main effect of nitrogen, however, was found insignificant.

The results obtained from chemical analysis of the monthly taken leaf samples are summarized in APPENDICES $1-5$, respectively for $\%$ nitrogen, $\%$ phosphorus, $\%$ potassium, \% calcium and \% magnesium for the period August 1959 to August 1960.

Highly significant and significant positive effects of increased potash dressings upon the leaf-potassium content were consistently assessed during the above period, except in August 1960.

No significant effects of increased nitrogen dressings upon the $\mathrm{N}$-leaf content were however assessed, except in March and April 1960, i.e. at the onset and during the early rains after the dry season (TABLE 1).

Consistent depressing effects of increased potash dressings upon the leaf-magnesium content were obtained during the period of investigation. However, slightly prior to and during the period when most of the plants had started to shoot, both the positive main effect of potash upon the leaf-potassium content and the negative main effect of potash upon leaf-magnesium content ceased to be significant (August 1960). A possible explanation may be sought in the assumption that during development and ripening of the fruit, the potassium is transferred from the leaves to the fruit, as is for example also the case in oilpalms.

Differences in soil-potassium levels are then likely to be reflected by bunch weight rather than by the leaf-potassium content.

Leaf-potassium contents are of considerable interest. Whereas slight differences exist between the $2 \mathrm{~K}$ - and $3 \mathrm{~K}$-treatments in the leaf-potassium content, the differences between $2 \mathrm{~K}$ and $3 \mathrm{~K}$ on one hand and control and $1 \mathrm{~K}$ on the other hand are quite pronounced, particularly in the middle of the dry season (January). This is shown in TABLE 3 .

TABLE 3. Mean leaf-potassium content for $1 \mathrm{~K}-, 2 \mathrm{~K}$ - and $3 \mathrm{~K}$-treatments and levels of significance for main effect of $\mathrm{K}$ during indicated months (Mean of 4 replications)

\begin{tabular}{|c|c|c|c|c|c|}
\hline Month & $\begin{array}{l}\text { Control } \\
\text { (1 plot) }\end{array}$ & $1 \mathrm{~K}$ & $2 \mathrm{~K}$ & $3 \mathrm{~K}$ & $\begin{array}{c}\text { Level of } \\
\text { significance }\end{array}$ \\
\hline August 1959 & 5,08 & 5,62 & 5,91 & 5,74 & - \\
\hline September $\ldots \ldots \ldots$ & 5,10 & 5,62 & 6,14 & 5,72 & $4,37^{*}$ \\
\hline October . & 5,04 & 4,74 & 4,65 & 5,04 & - \\
\hline November & 4,95 & 4,72 & 5,03 & 5,09 & $6,83 * *$ \\
\hline December . . & 4,27 & 4,51 & 4,85 & 4,95 & $9,05 * *$ \\
\hline January $1960 \ldots \ldots$ & 4,45 & 4,27 & 4,67 & 4,61 & $21,4^{* * *}$ \\
\hline February $\quad \ldots \ldots \ldots$ & 3,38 & 3,83 & 4,67 & 4,21 & $4,74 *$ \\
\hline$\ldots \ldots \ldots \ldots$ & 3,93 & 3,82 & 4,03 & 4,07 & $4,02 *$ \\
\hline April & 3,62 & 3,86 & 4,12 & 4,73 & $5,19 *$ \\
\hline$\ldots \ldots$ & 3,48 & 3,87 & 4,04 & 4,23 & $3,40\left(^{*}\right)$ \\
\hline$\ldots \ldots \ldots \ldots$ & 4,33 & 4,15 & 4,47 & 4,58 & $4,22 *$ \\
\hline July . . & 3,70 & 4,29 & 4,24 & 4,57 & $5,59 *$ \\
\hline$\ldots \ldots \ldots \ldots$ & 4,21 & 4,28 & 4,65 & 4,48 & - \\
\hline
\end{tabular}

* $P(x \geqq 3,68 / 2 ; 15)=0,05$

** $\quad P(x \geq 6,36 / 2 ; 15)=0,01$

*** $\quad P(x \geqq 11,34 / 2 ; 15)=0,001$

As was stated previously, the period of leaf recording covered the drier part of the year, i.e. from October to April. The fact that highly significant main effects of 
potash upon leaf-potassium content were obtained in this particular period is therefore not surprising.

Exchangeable potassium is likely to be much reduced in the dry season and potash fertiliser applications in the dry season will increase thus the availability of $K$ in the $2 \mathrm{~K}$ - and $3 \mathrm{~K}$-plots as compared with the $1 \mathrm{~K}$-plots in a more pronounced way than it will be the case in the wet season.

Leaf production during October 1959-April 1960 was correlated with the average nutrient content during the same period. The results are summarized in TABLE 4.

TABLE 4. Relationships between leaf production (October 1959-April 1960) per plant and average mineral content of the first leaf during the same period

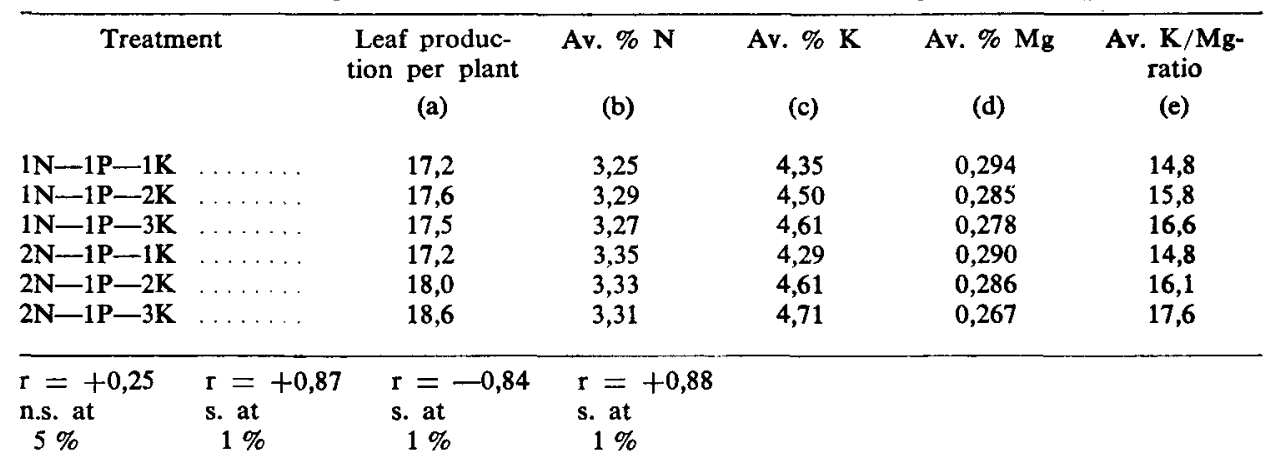

The depressing effect of potash upon leaf magnesium is further substantiated by columns (d) and (e) of TABLE 4. However, no symptoms of magnesium deficiency as described by MurRay (1959) were noticeable in the 2K- and 3K-plots. Moreover, it is well known that young volcanic soils derived from basaltic parent rock are well supplied with the easily weathering magnesium containing olivine mineral (MOHR and VAN BAREN, 1954).

In TABLE 5 the effect is shown of increasing nitrogen and/or potash dressings on bunch weight, hand weight and hands per stem.

TABLE 5. Lacatan bananas (plant crop): Mean bunch weight and mean hand weight (in $\mathrm{kg}$ full grade) and hands/stem (Mean of 4 replications)

\begin{tabular}{|c|c|c|c|c|c|c|}
\hline \multirow[t]{2}{*}{ Treatments } & \multicolumn{3}{|c|}{$\begin{array}{l}\text { To date } 2 \text { quarters } \\
\text { July '60-Dec. } 60 \text { (a) }\end{array}$} & \multicolumn{3}{|c|}{$\begin{array}{l}\text { To date } 3 \text { quarters } \\
\text { July '60-March '61 (b) }\end{array}$} \\
\hline & $\begin{array}{c}\text { Bunch weight } \\
(\mathrm{kg})\end{array}$ & $\begin{array}{l}\text { Hand weight } \\
\text { (kg) }\end{array}$ & $\begin{array}{l}\text { Hands/stem } \\
\text { (Number) }\end{array}$ & $\begin{array}{c}\text { Bunch weight } \\
(\mathrm{kg})\end{array}$ & $\begin{array}{l}\text { Hand weight } \\
\text { (kg) }\end{array}$ & $\begin{array}{c}\text { Hands/stem } \\
\text { (Number) }\end{array}$ \\
\hline IN-1P-IK & 29,75 & 3,82 & 7,8 & 31,25 & 3,92 & 7,9 \\
\hline $1 N-1 P-2 K$ & 34,25 & 4,04 & 8,5 & 34,25 & 4,08 & 8,4 \\
\hline $1 N-1 P-3 K$ & 34,75 & 4,14 & 8,4 & 34,25 & 4,20 & 8,1 \\
\hline $2 \mathrm{~N}-1 \mathrm{P}-1 \mathrm{~K}$ & 30,25 & 3,83 & 7,9 & 30,75 & 3,95 & 7,8 \\
\hline $2 \mathrm{~N}-1 \mathrm{P}-2 \mathrm{~K}$ & 33,25 & 4,03 & 8,3 & 34,25 & 4,16 & 8,2 \\
\hline $2 \mathrm{~N}-1 \mathrm{P}-3 \mathrm{~K}$ & 36,50 & 4,25 & 8,6 & 36,50 & 4,30 & 8,5 \\
\hline
\end{tabular}

All experimental plots produced fruit in the last two quarters of 1960 except one $1 \mathrm{~N}-1 \mathrm{P}-1 \mathrm{~K}$-treatment plot. At the end of the 3rd quarter (March 1961) however all plots had produced fruit.

Neth. J. agric. Sci., Vol. 10 (1962) No. 2 (May) 
Highly significant effects of increased potash dressings, both as a treatment and its main effect (TABLE 5b), were obtained upon mean bunch weight and hand weight whilst the effect of increased potash dressings upon number of hands per stem was found to be significant. Effects of increased nitrogen dressings appeared to be non-significant.

Mean bunch weight (TABLE 5 a) was correlated with average \% K (TABLE 4) during October 1959-April 1960 and leaf production per plant (TABLE 4) during the same period. This is shown in TABLE 6.

TABLE 6. Relationships between mean bunch weight and average leaf-potassium content during October 1959-April 1960 and leaf production per plant during the same period

\begin{tabular}{|c|c|c|c|}
\hline Treatment & $\begin{array}{c}\text { Mean } \\
\text { bunch weight }\end{array}$ & Average $\% \mathbf{K}$ & $\begin{array}{l}\text { Average leaf } \\
\text { production }\end{array}$ \\
\hline $1 \mathrm{~N}-1 \mathrm{P}-1 \mathrm{~K}$ & 29,75 & 4,35 & 17,2 \\
\hline $1 \mathrm{~N}-1 \mathrm{P}-2 \mathrm{~K} \ldots \ldots$ & 34,25 & 4,50 & 17,6 \\
\hline $1 \mathrm{~N}-1 \mathrm{P}-\mathbf{3 K} \ldots \ldots$ & 34,75 & 4,61 & 17,5 \\
\hline $2 \mathrm{~N}-1 \mathrm{P}-1 \mathrm{~K} \ldots \ldots$ & 30,25 & 4,29 & 17,2 \\
\hline $2 \mathrm{~N}-1 \mathbf{P}-2 \mathrm{~K} \quad \ldots \ldots$ & 33,25 & 4,61 & 18,0 \\
\hline $2 \mathrm{~N}-1 \mathrm{P}-3 \mathrm{~K} \ldots \ldots$ & 36,50 & 4,71 & 18,6 \\
\hline
\end{tabular}

$r=+0,81 \quad r=+0,72$

n.s. at $1 \%$ s. at $5 \%$

It may be calculated from TABLE 6 that the percentage increase in mean bunch weight is reflected by a percentage increase in K-leaf content of about half as much as the percentage increase in mean bunch weight.

Irrigation facilities on a large scale are not present in the Southern Cameroons except in some limited areas along the coast. Most of the banana plantations, however, cover the young volcanic non-irrigated areas.

The planting season is restricted to the period preceeding the main rainy season. The production of leaves in the first $4-5$ months (i.e. when in general sufficient water is available for plant growth) is, as was previously suggested, mainly determined by the size of and the nutrient reserves in the corm. Subsequently, the production of leaves will be affected by the rate of water supply in the dry season.

As previously mentioned, increased potash dressings nearly significantly promoted leaf production whilst the leaf-potassium content highly significantly correlated with leaf production during the dry season. The latter is likely to be the result of a better balanced water economy of the plant (HaSSELO, 1961).

Potash fertilizing at the onset of the dry season is thus particularly important in that it compensates for the lack of water supply in the dry season. Moreover, as was shown in this paper, both production and quality of fruit were improved up to one year afterwards.

Too low leaf-potassium values at the onset of the dry seascn can successfully be detected by means of foliar diagnosis and corrected by additional potash dressings prior to the dry season.

\section{ACKNOWLEDGEMENTS}

The authors wish to thank Mr. J. N. EFITE for his help with the sampling and the chemical analysis, Messrs. R. S. DIXoN and D. J. EAsT for the field recording, and the Management of the Cameroons Development Corporation for having read this paper with interest. 
FOLIAR ANALYSIS IN EXPERIMENTALLY GROWN LACATAN BANANAS . .

APPENDIX 1. \% Nitrogen in first leaf

\begin{tabular}{|c|c|c|c|c|c|c|c|c|c|c|c|c|c|}
\hline & Aug. & Sept. & Oct. & Nov. & Dec. & Jan. & Feb. & Ma. & Apr. & May & June & July & Aug. \\
\hline NPK & 3,75 & 3,74 & 3,47 & 3,99 & 3,34 & 3,03 & 2,82 & 2,86 & 3,22 & 3,27 & 3,39 & 3,04 & 2,34 \\
\hline NP2K & 3,81 & 3,64 & 3,72 & 4,09 & 3,29 & 3,03 & 2,83 & 2,76 & 3,23 & 3,23 & 3,23 & 3,41 & 2,62 \\
\hline NP3K & 3,66 & 3,75 & 3,67 & 4,02 & 3,29 & 3,06 & 2,80 & 2,78 & 3,19 & 3,22 & 3,37 & 3,12 & 2,67 \\
\hline 2NPK & 3,79 & 3,77 & 3,76 & 4,15 & 3,38 & 3,10 & 2,86 & 2,87 & 3,38 & 3,42 & 3,33 & 3,34 & 2,55 \\
\hline 2NP2K & 3,81 & 3,67 & 3,85 & 4,07 & 3,34 & 3,07 & 2,79 & 2,83 & 3,36 & 3,17 & 3,45 & 3,29 & 2,45 \\
\hline 2NP3K & 3,66 & 3,80 & 3,60 & 4,17 & 3,38 & 3,07 & 2,78 & 2,86 & 3,41 & 3,22 & 3,41 & 3,31 & 2,86 \\
\hline Control & 4,21 & 4,17 & 3,92 & 4,04 & 3,12 & 3,04 & 2,95 & 2,90 & 3,39 & 3,30 & 3,41 & 3,31 & 3,09 \\
\hline
\end{tabular}

Appendix 2. \% Phosphorus in first leaf

\begin{tabular}{|c|c|c|c|c|c|c|c|c|c|c|c|c|c|}
\hline & Aug. & Sept. & Oct. & Nov. & Dec. & Jan. & Feb. & Ma. & Apr. & May & June & July & Aug. \\
\hline NPK & 0,347 & 0,348 & 0,275 & 0,290 & 0,288 & 0,255 & 0,256 & 0,222 & 0,246 & 0,247 & 0,289 & 0,302 & 0,307 \\
\hline NP2K & 0,347 & 0,394 & 0,290 & 0,288 & 0,282 & 0,259 & 0,272 & 0,227 & 0,252 & 0,239 & 0,304 & 0,290 & 0,299 \\
\hline NP3K & 0,339 & 0,360 & 0,297 & 0,298 & 0,276 & 0,264 & 0,277 & 0,229 & 0,245 & 0,239 & 0,293 & 0,303 & 0,308 \\
\hline 2NPK & 0,336 & 0,356 & 0,273 & 0,285 & 0,275 & 0,256 & 0,263 & 0,221 & 0,239 & 0,235 & 0,291 & 0,281 & 0,287 \\
\hline 2NP2K & 0,356 & 0,383 & 0,288 & 0,306 & 0,259 & 0,258 & 0,257 & 0,220 & 0,253 & 0,237 & 0,273 & 0,275 & 0,282 \\
\hline 2NP3K & 0,355 & 0,368 & 0,290 & 0,305 & 0,277 & 0,256 & 0,260 & 0,226 & 0,246 & 0,238 & 0,293 & 0,286 & 0,290 \\
\hline Control & 0,303 & 0,311 & 0,292 & 0,323 & 0,287 & 0,280 & 0,271 & 0,223 & 0,257 & 0,269 & 0,326 & 0,290 & 0,293 \\
\hline
\end{tabular}

Appendix 3. \% Potassium in first leaf

\begin{tabular}{|c|c|c|c|c|c|c|c|c|c|c|c|c|c|}
\hline & Aug. & Sept. & Oct. & Nov. & Dec. & Jan. & Feb. & Ma. & Apr. & May & June & July & Aug. \\
\hline NPK & 5,62 & 5,66 & 4,74 & 4,72 & 4,56 & 4,30 & 3,95 & 3,83 & 3,93 & 3,99 & 4,14 & 4,52 & 4,29 \\
\hline NP2K & 5,99 & 6,28 & 4,51 & 4,91 & 4,86 & 4,69 & 4,06 & 3,95 & 4,09 & 4,12 & 4,66 & 4,37 & 4,77 \\
\hline NP3K & 5,64 & 5,73 & 5,00 & 5,08 & 4,92 & 4,57 & 4,17 & 3,93 & 4,42 & 4,34 & 4,55 & 4,65 & 4,31 \\
\hline 2NPK & 5,61 & 5,67 & 4,75 & 4,72 & 4,47 & 4,24 & 3,71 & 3,82 & 3,80 & 3,75 & 4,16 & 4,07 & 4,28 \\
\hline 2NP2K & 5,83 & 6,00 & 4,80 & 5,16 & 4,84 & 4,65 & 4,08 & 4,11 & 4,14 & 3,96 & 4,28 & 4,12 & 4,54 \\
\hline 2NP3K & 5,87 & 5,71 & 5,09 & 5,10 & 4,97 & 4,65 & 4,25 & 4,21 & 4,05 & 4,12 & 4,61 & 4,49 & 4,65 \\
\hline Control & 5,08 & 5,10 & 5,04 & 4,95 & 4,27 & 4,45 & 3,38 & 3,93 & 3,62 & 3,48 & 4,33 & 3,70 & 4,21 \\
\hline
\end{tabular}

APPENDIX 4. \% Calcium in first leaf

\begin{tabular}{lccccccccccccc}
\hline & Aug. & Sept. & Oct. & Nov. & Dec. & Jan. & Feb. & Ma. & Apr. & May & June & July & Aug. \\
NPK & 0,480 & 0,545 & 0,525 & 0,533 & 0,521 & 0,556 & 0,528 & 0,582 & 0,583 & 0,554 & 0,583 & 0,604 & 0,623 \\
NP2K & 0,510 & 0,556 & 0,537 & 0,590 & 0,572 & 0,503 & 0,525 & 0,570 & 0,560 & 0,533 & 0,556 & 0,567 & 0,612 \\
NP3K & 0,493 & 0,499 & 0,511 & 0,553 & 0,527 & 0,526 & 0,534 & 0,557 & 0,547 & 0,587 & 0,591 & 0,608 & 0,628 \\
2NPK & 0,502 & 0,535 & 0,524 & 0,526 & 0,513 & 0,528 & 0,571 & 0,574 & 0,607 & 0,617 & 0,619 & 0,642 & 0,649 \\
2NP2K & 0,526 & 0,532 & 0,523 & 0,512 & 0,508 & 0,527 & 0,536 & 0,573 & 0,609 & 0,618 & 0,632 & 0,639 & 0,675 \\
2NP3K & 0,506 & 0,539 & 0,518 & 0,522 & 0,516 & 0,522 & 0,541 & 0,552 & 0,525 & 0,592 & 0,605 & 0,622 & 0,676 \\
Control & 0,590 & 0,571 & 0,585 & 0,591 & 0,529 & 0,557 & 0,550 & 0,555 & 0,601 & 0,612 & 0,612 & 0,621 & 0,614 \\
\hline
\end{tabular}

APPENDIX 5. \% Magnesium in first leaf

\begin{tabular}{lccccccccccccc}
\hline & Aug. & Sept. & Oct. & Nov. & Dec. & Jan. & Feb. & Ma. & Apr. & May & June & July & Aug. \\
NPK & 0,317 & 0,294 & 0,286 & 0,315 & 0,278 & 0,314 & 0,291 & 0,278 & 0,295 & 0,251 & 0,294 & 0,335 & 0,287 \\
NP2K & 0,314 & 0,272 & 0,260 & 0,315 & 0,257 & 0,310 & 0,296 & 0,269 & 0,271 & 0,247 & 0,288 & 0,309 & 0,274 \\
NP3K & 0,288 & 0,275 & 0,265 & 0,299 & 0,256 & 0,288 & 0,281 & 0,279 & 0,268 & 0,235 & 0,264 & 0,294 & 0,257 \\
2NPK & 0,293 & 0,281 & 0,275 & 0,301 & 0,279 & 0,313 & 0,294 & 0,285 & 0,286 & 0,270 & 0,326 & 0,325 & 0,280 \\
2NP2K & 0,296 & 0,289 & 0,275 & 0,314 & 0,267 & 0,307 & 0,286 & 0,264 & 0,289 & 0,248 & 0,259 & 0,313 & 0,279 \\
2NP3K & 0,287 & 0,271 & 0,247 & 0,294 & 0,242 & 0,274 & 0,272 & 0,272 & 0,256 & 0,237 & 0,283 & 0,287 & 0,255 \\
Control & 0,319 & 0,299 & 0,289 & 0,335 & 0,299 & 0,330 & 0,281 & 0,317 & 0,288 & 0,263 & 0,337 & 0,314 & 0,291 \\
\hline
\end{tabular}




\section{REFERENCES}

Anon.

BOLAND, D.

BRoEshaRT, $\mathrm{H}$.

Hasselo, H. N.

HewitT, C. $\mathbf{H}$.

MoHr, E. C. J., and F. A. VAN BAREN

MURRAY, D. B.

Prevot, P., et M. Ollagnier RISBETH, J.
1959 W.A.I.F.O.R., Quarterly Progress Report. No. 28.

1957/58 Banana Board Research Department, Jamaica. Annual Report.

1955 The application of foliar analysis in oil palm cultivation. Thesis, Wageningen.

1961a Premature yellowing of Lacatan bananas. Trop. Agr. Trin. 38, $1: 29-35$.

1961b The soils of the lower eastern slopes of the Cameroon Mountain and their suitability for various perennial crops. Thesis, Wageningen.

1955 Leaf analysis as a guide to the nutrition of bananas. Emp. J. Exp. Agr. 23, No. 89.

1954 Tropical Soils - A critical study of soil genesis as related to climate, rock and vegetation. The Hague.

1959 Deficiency symptoms of the major elements in the banana. Trop. Agr. Trin. 36, p. 100.

1960 The effect of deficiencies of the major nutrients on growth and leaf analyses of the banana. Trop. Agr. Trin. 37, 2 97-107.

1953 Oleagineux. $67-71$ et $843-851$.

1960 Factors affecting the incidence of Banana Wilt (Panama Disease). Emp. J. Exp. Agr. 28, p. 110. 